\title{
Deschampsia cespitosa subsp. parviflora (Poaceae) - an under-recorded woodland grass
}

\author{
Andy Amphlett* \\ Grantown on Spey, Scotland
}

*Corresponding author: Andy Amphlett, email: amphlett1958@gmail.com

This pdf constitutes the Version of Record published on $21^{\text {st }}$ May 2019

\begin{abstract}
Deschampsia cespitosa (L.) P. Beauv. subsp. parviflora (Thuill.) Dumort was, to British and Irish botanists, a little known taxon prior to1988, and current distribution mapping shows a marked geographical recording bias. It is confirmed as being primarily a woodland taxon, at low altitudes; modal mean altitude 50-75 m AOD, with $97 \%$ of locations at $\leq 300 \mathrm{~m} \mathrm{AOD}$. A combination of woodland or shaded habitat, bright green narrow leaves, and delicate panicle, with small spikelets, is suggestive of subsp. parviflora. In combination, degree of leaf blade scabridity on the adaxial surface, appearance of papillae on flat surfaces of adaxial ridges of the leaf, and spikelet length, provide the most reliable means of distinguishing this subspecies from subsp. cespitosa. There is no reason to suspect that subsp. parviflora is increasing, rather it had previously been overlooked.
\end{abstract}

\section{Key Words}

Identification; recording bias; altitudinal range; habitat; tufted hair-grass.

\section{Introduction}

In British and Irish Floras, Deschampsia cespitosa (L.) P. Beauv. subsp. parviflora (Thuill.) Dumort, was first mentioned (at varietal level) in the first edition of the Flora of the British Isles (Clapham et al 1952). However, it was not until the more detailed account in the Plant Crib (McAllister 1988), that this taxon became more widely known, and there was a rapid increase in recording, as documented by records in the Distribution Database maintained by the Botanical Society of Britain and Ireland (https://database.bsbi.org/), henceforth referred to as the 'BSBI database' (Fig. 1).

Although aware of subsp. parviflora, it was not until 2015 that I first found distinctive examples of this subspecies, at two sites in Derbyshire (v.c.57). This encouraged me to follow up an old Easterness (v.c.96) record in 2016, but without success. On 1st June 2017, accompanied by Linda Henderson, I visited an area of woodland at Ferness in the valley of the River Findhorn (v.c.96) to see a newly found population of Bird's-nest Orchid Neottia nidus-avis. Almost as soon as we entered the wood, we came across tens of small tussocks of a non-flowering graminoid plant, with bright grass-green, narrow leaves (Fig. 2), that I initially took to be Remote Sedge Carex remota, a rather local species in north Scotland. On closer examination of the leaves, and pulling apart an unopened inflorescence, I 
realised the tussocks were of $D$. cespitosa. I returned on 11th June, when several tussocks had \pm open panicles, to collect specimens for closer examination, confirming that the plants were indeed $D$. cespitosa subsp. parviflora.

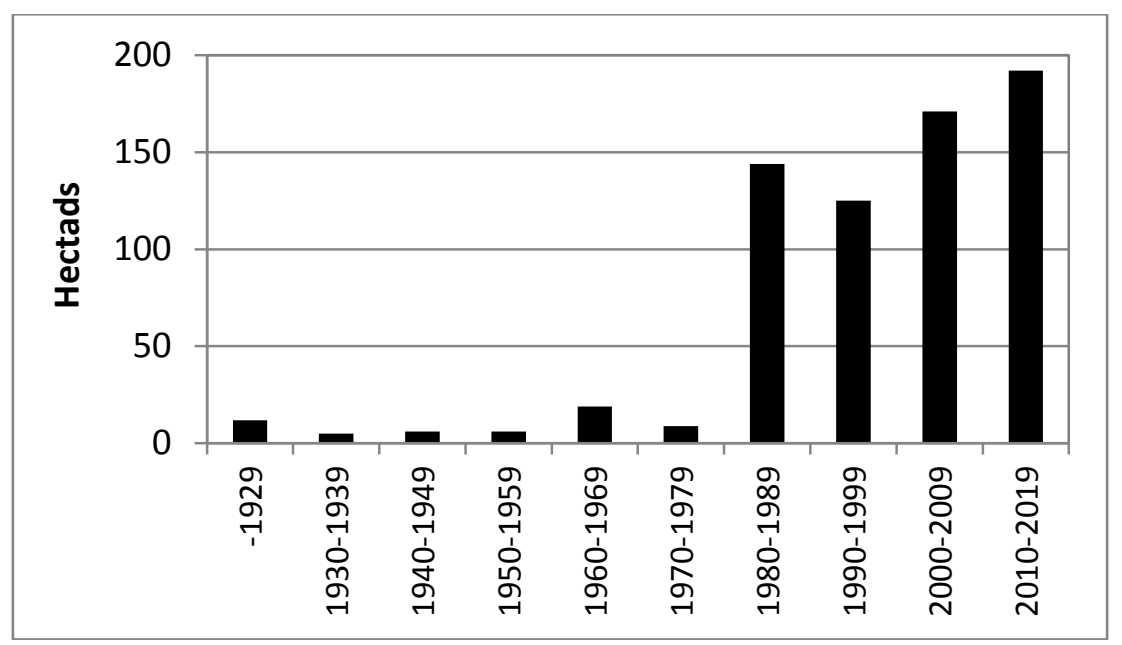

Figure 1. Deschampsia cespitosa subsp. parviflora. Number of hectads per decade in GB and Ireland, based on records in the BSBI database.

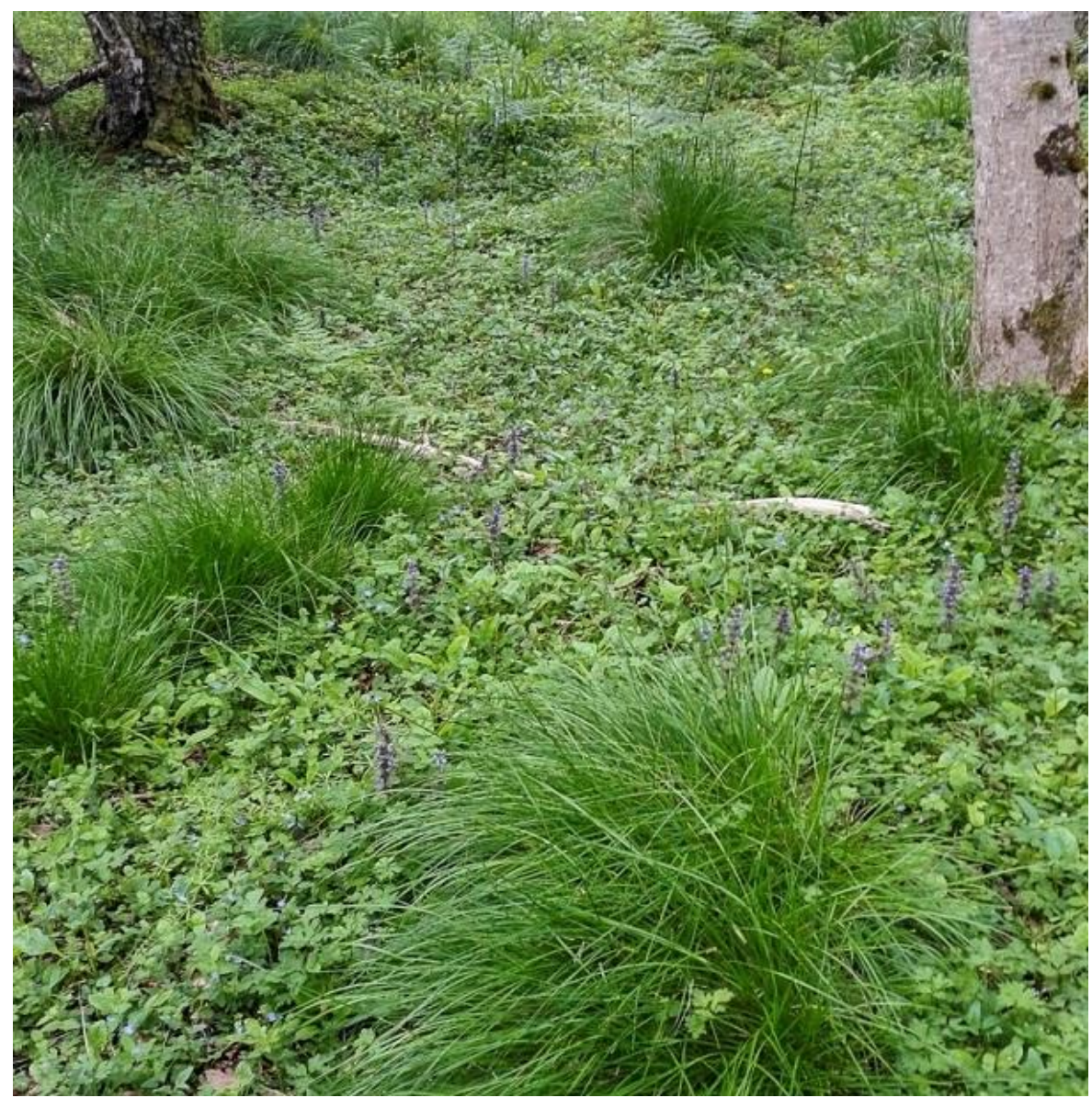

Figure 2. Deschampsia cespitosa subsp. parviflora: Ferness (River Findhorn) (v.c.96) June 2017. 
During June 2017, I found additional stands of D. cespitosa subsp. parviflora at three more locations in the River Findhorn valley, and beside a tributary of this river (Fig. 3). I also found plants at a single site in Glen Affric (v.c.96). In July 2017, I found plants at an additional site in v.c.57 and in Staffordshire (v.c.39).

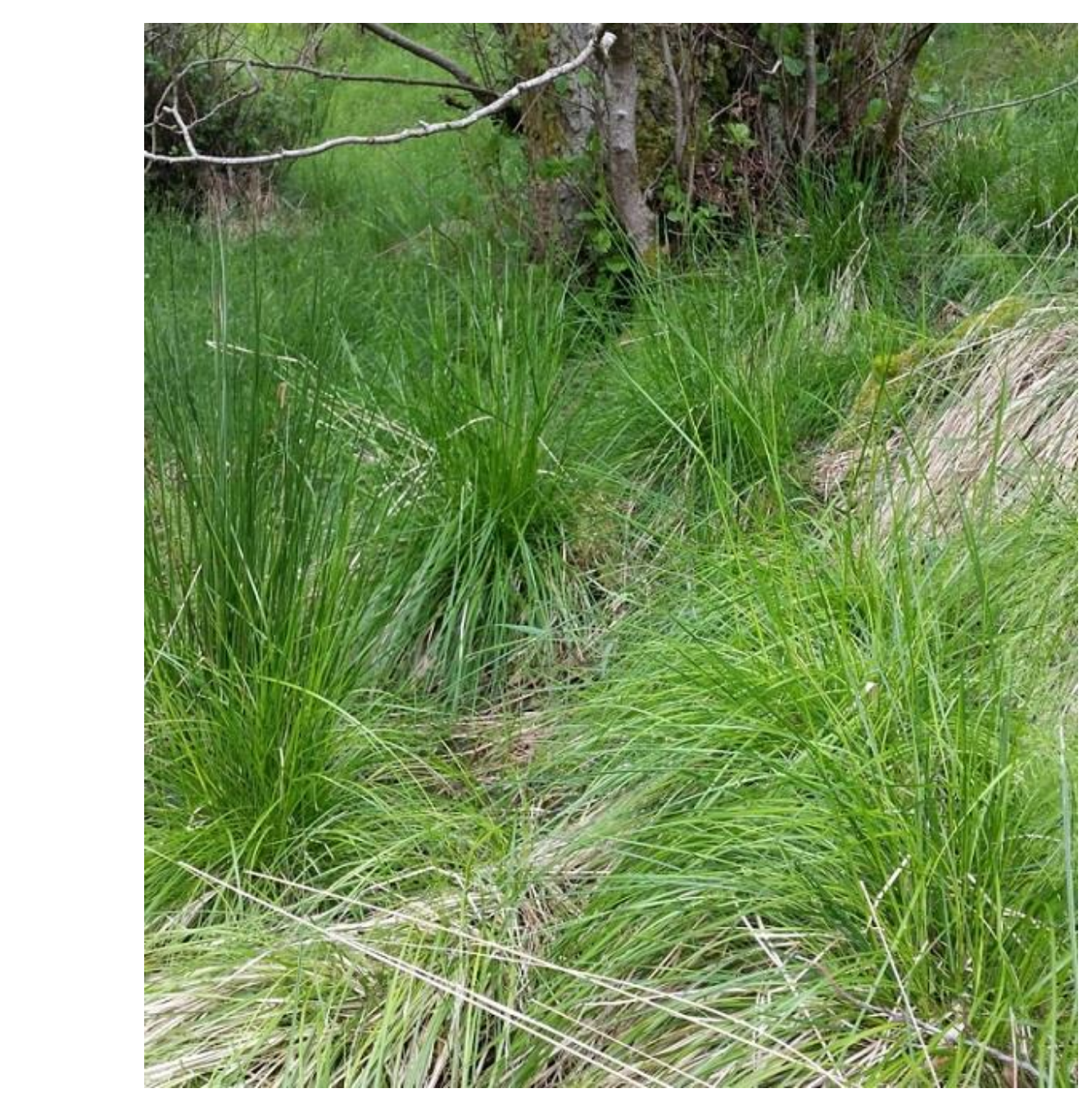

Figure 3. Deschampsia cespitosa subsp. parviflora: Tomnarroch Burn (v.c.96) June 2017.

\section{Distribution}

On current knowledge, within the BSBI recording area, $D$. cespitosa subsp. parviflora is almost restricted to England, Wales and Scotland, which account for $98 \%$ of the recorded hectad range (Table 1 ). There is a single record from the Isle of Man (v.c.71) collected in 1950. There are no records from the Channel Isles (v.c.113). In Ireland, there are un-localised 1967 / 1968 records from woodland in Co. Clare (H09), North Kerry (H02) and Co. Cavan (H30), (Farragher 1969); these are not included in Table 1. The first localised record was in 1999 (Dines 2000) in a 'wonderful fragment of deciduous woodland south of Easky' (Co. Sligo). In N. Ireland, John Harron reported this subspecies from Co. Armagh (H37) in 2005, and in four hectads in Co. Antrim (H39) between 2006 and 2016.

In Scotland, excluding the author's recent finds, there are 41 distinct records, from 37 locations, in 34 hectads, in 14 vice-counties. There are concentrations of 
records in Fife (v.c.85) 11 hectads, and in Ayrshire (v.c.75) 5 hectads. North of the central belt, all but one of the post-1999 records are by the author or George Ballantyne.

Table 1. Deschampsia cespitosa subsp. parviflora. Number of hectads up to and post-1999. Based on records in the BSBI database.

\begin{tabular}{|l|r|r|r|}
\hline & $\begin{array}{c}\text { Pre- } \\
\mathbf{2 0 0 0}\end{array}$ & $\mathbf{2 0 0 0 -}$ & Total \\
\hline England & 194 & 249 & 352 \\
\hline Wales & 29 & 28 & 49 \\
\hline Scotland & 29 & 9 & 36 \\
\hline N. Ireland & 0 & 5 & 5 \\
\hline Ireland & 1 & 0 & 1 \\
\hline Isle of Man & 1 & 0 & 1 \\
\hline
\end{tabular}

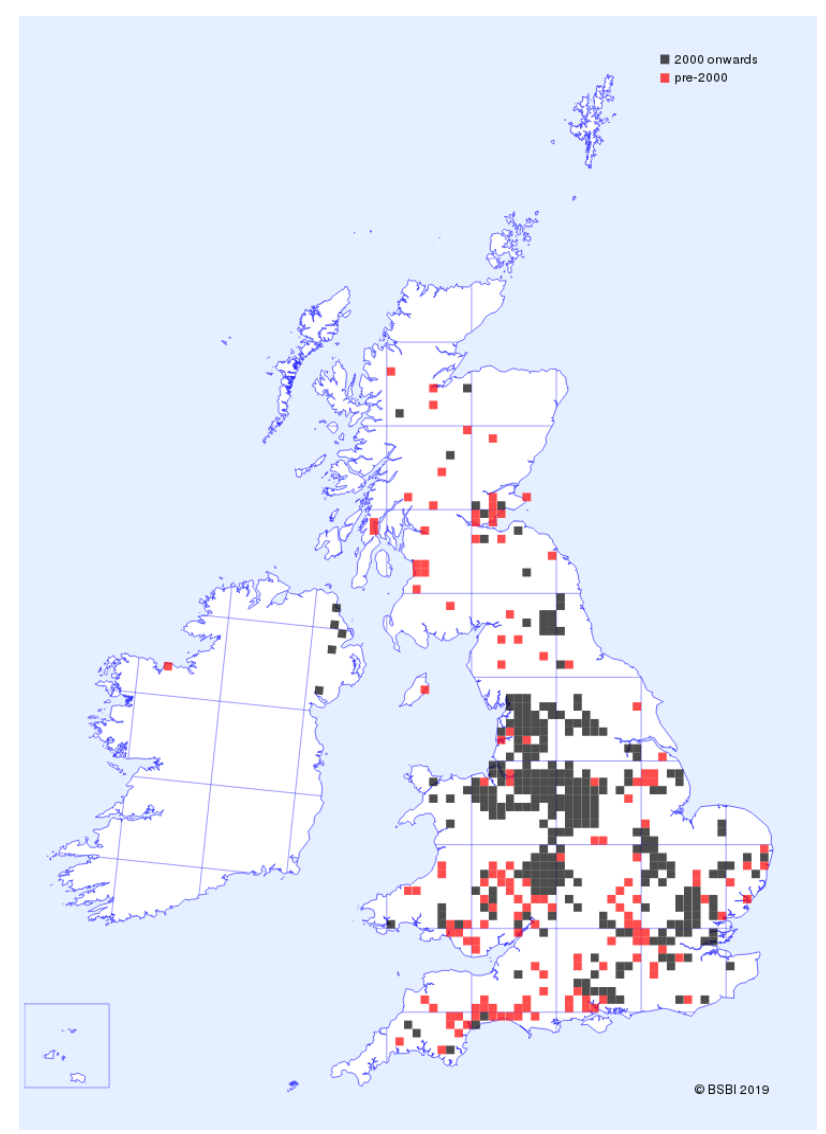

Figure 4. Deschampsia cespitosa subsp. parviflora hectad distribution map. (From BSBI database 14/2/2019). Black (post-1999), red (pre-2000).

The hectad distribution map (Fig. 4), is strongly suggestive of a geographical recording bias, with marked concentrations of records in (inter alia) Worcestershire (v.c.37), Denbighshire (v.c.50), Derbyshire (v.c.57), Cheshire (v.c.58), and South and West Lancashire (v.c.s 59,60). The recording bias is especially pronounced post-1999. 


\section{Habitat}

Floras and other published accounts broadly agree on the habitat within which this subspecies occurs: woodland on heavy soils (Clapham et al 1987); woods \& shady hedgerows (Stace 2019); woods \& shady places, especially on heavy soils (Sell \& Murrell 1996); lowland woods on heavy soils (Cope and Gray 2009); lowland woodland (Parnell and Curtis 2012); damp shady places on heavy soils (Hubbard 1984); shaded places in ancient woodland (McAllister 1998). Of the 1550 records of D. cespitosa subsp. parviflora on the BSBI database (DDb) (at February 2019), 150 records have some indication of habitat. Of these 150 records, $130(87 \%)$ refer to woodland or shade. Habitat and associated species of populations of $D$. cespitosa subsp. parviflora found by the author in 2017, are summarised in Table 2.

Table 2. Habitat and associated species of populations of $D$. cespitosa subsp. parviflora found by the author in 2017 in v.c.s 39, 57 and 96.

\begin{tabular}{|c|c|c|c|}
\hline vc & Locality & $\begin{array}{l}\text { Grid } \\
\text { reference }\end{array}$ & Habitat \& associated species \\
\hline 39 & $\begin{array}{l}\text { Coldwall Bridge } \\
\text { (S. of) }\end{array}$ & SK14874958 & $\begin{array}{l}\text { On bank by track under Acer } \\
\text { pseudoplatanus, Crataegus monogyna, } \\
\text { Fraxinus excelsior and Ulmus glabra, } \\
\text { with Circaea lutetiana and Mercurialis } \\
\text { perennis. }\end{array}$ \\
\hline 39 & $\begin{array}{l}\text { Coldwall Bridge } \\
\text { (SW of) }\end{array}$ & SK14844963 & $\begin{array}{l}\text { Bank by track under } C . \text { monogyna } \& \\
\text { Rosa sp.. }\end{array}$ \\
\hline 39 & $\begin{array}{l}\text { Coldwall Bridge } \\
\text { (SE of) }\end{array}$ & SK15224959 & $\begin{array}{l}\text { Under } A . \text { pseudoplatanus \& U. glabra, } \\
\text { with Dryopteris filix-mas, Epilobium } \\
\text { montanum, Galium odoratum, Geranium } \\
\text { robertianum, Hypericum hirsutum, M. } \\
\text { perennis, Rubus fruticosus agg.. }\end{array}$ \\
\hline 57 & Miller's Dale & SK138731 & $\begin{array}{l}\text { In north facing woodland, with Sanicula } \\
\text { europaea. }\end{array}$ \\
\hline 57 & $\begin{array}{l}\text { Carsington Water: } \\
\text { Shiningford Farm } \\
\text { (SE of) }\end{array}$ & SK24635226 & In woodland by FP. \\
\hline 57 & $\begin{array}{l}\text { Carsington Water: } \\
\text { Sheepwash Car } \\
\text { Park (NE of) }\end{array}$ & SK25035297 & $\begin{array}{l}\text { In woodland with Bromopsis ramosa, } \\
\text { Dryopteris dilatata, F. excelsior, Geum } \\
\text { urbanum, } R \text {. fruticosus agg., Sambucus } \\
\text { nigra, Urtica dioica. }\end{array}$ \\
\hline 57 & Via Gellia & SK265565 & $\begin{array}{l}\text { In north facing woodland, with Melica } \\
\text { uniflora. }\end{array}$ \\
\hline 96 & $\begin{array}{l}\text { Allt na Ciche } \\
\text { (W. side of) }\end{array}$ & NH12091922 & Under Alnus glutinosa, close to burn. \\
\hline 96 & $\begin{array}{l}\text { River Findhorn (S. } \\
\text { side): Dulsie } \\
\text { Bridge (upstream } \\
\text { of) }\end{array}$ & NH92664042 & $\begin{array}{l}\text { On steep flushed slope under } A \text {. } \\
\text { glutinosa. Associate species incl. } \\
\text { Veronica montana, Circaea } x \text { intermedia, } \\
\text { Stellaria holostea, Carex remota. Stellaria } \\
\text { nemorum a few metres away. }\end{array}$ \\
\hline
\end{tabular}




\begin{tabular}{|c|c|c|c|}
\hline 96 & $\begin{array}{l}\text { River Findhorn (SE } \\
\text { side): Dulsie } \\
\text { Bridge (upstream } \\
\text { of) }\end{array}$ & $\begin{array}{l}\text { NH92844056 } \\
\text { NH92844057 }\end{array}$ & $\begin{array}{l}\text { Flushed slope in woodland above river. } \\
\text { Associate species incl. Carex laevigata, } \\
\text { C. remota, Crepis paludosa. Canopy of } A \text {. } \\
\text { glutinosa \& Salix caprea. }\end{array}$ \\
\hline 96 & $\begin{array}{l}\text { River Findhorn (S. } \\
\text { side): Dulsie } \\
\text { Bridge (upstream } \\
\text { of) }\end{array}$ & NH92674041 & $\begin{array}{l}\text { On grassy slope, open area in woodland, } \\
\text { above river. Associate species incl. } \\
\text { Oreopteris limbosperma, S. holostea, } \\
\text { Holcus mollis, Rumex acetosa. }\end{array}$ \\
\hline 96 & $\begin{array}{l}\text { Tomnarroch Burn } \\
\text { (E. of) }\end{array}$ & NH96214406 & $\begin{array}{l}\text { In flushed } A \text {. glutinosa woodland on } \\
\text { slope near burn. }\end{array}$ \\
\hline 96 & Ferness (W. of) & NH96174486 & $\begin{array}{l}\text { In damp woodland. Associated species } \\
\text { Ajuga reptans, Ranunculus repens, } \\
\text { Veronica chamaedrys, with occasional } \\
\text { Lysimachia nemorum. Canopy of Betula } \\
\text { pubescens \& F. excelsior. }\end{array}$ \\
\hline 96 & Cairnglass (SW of) & $\begin{array}{l}\text { NH96044666 } \\
\text { NH96064665 }\end{array}$ & $\begin{array}{l}\text { On flushed slope under } A \text {. glutinosa. } \\
\text { Associate species incl. } \text { A. reptans, } \\
\text { Blechnum spicant, Caltha palustris, C. } \\
\text { laevigata, Carex paniculata, } \\
\text { Chrysosplenium oppositifolium, } \\
\text { Dryopteris affinis agg., D. dilatata, G. } \\
\text { robertianum, H. mollis, Juncus effusus, } \\
\text { Oxalis acetosella, } R \text {. acetosa. }\end{array}$ \\
\hline
\end{tabular}

\section{Altitudinal range}

There are records of $D$. cespitosa subsp. parviflora on the BSBI database from 1057 unique grid references, at tetrad or better precision. Mean altitude for each grid cell was calculated and plotted against the number of unique grid references (Fig. 5).

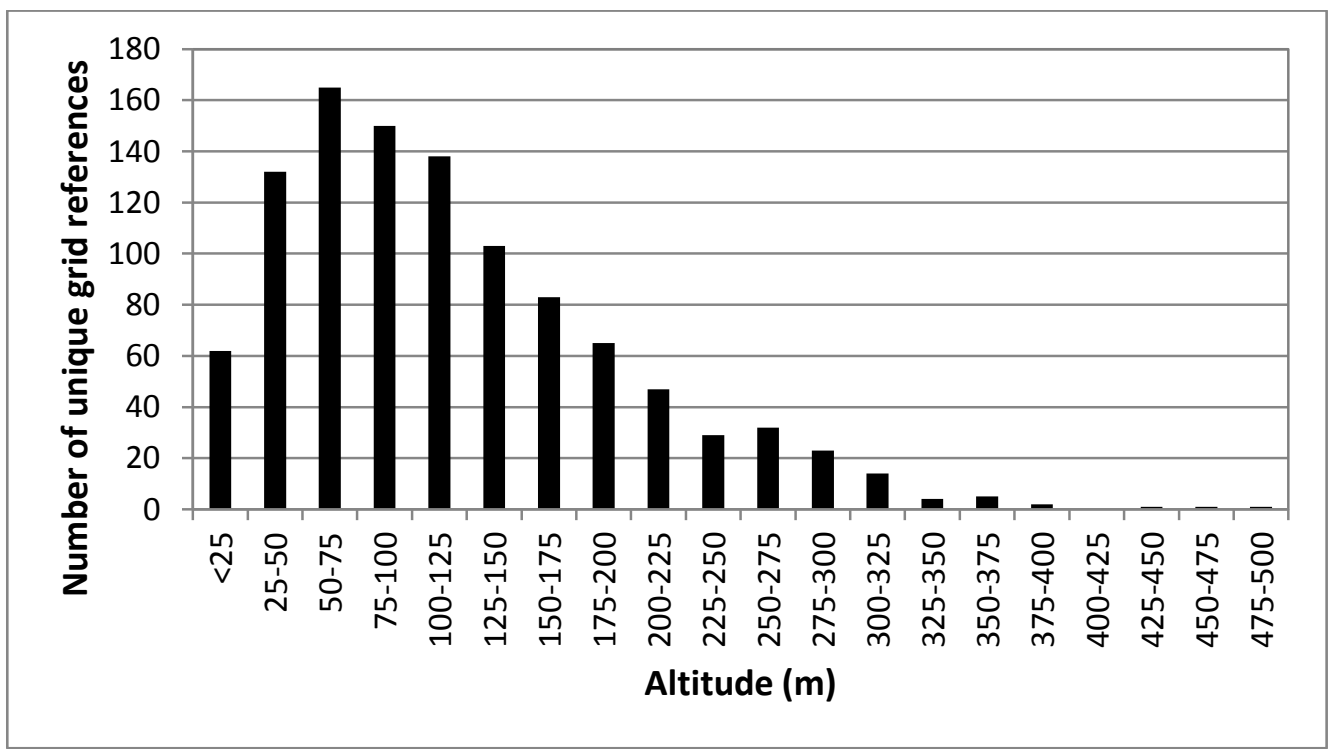

Figure 5. Deschampsia cespitosa subsp. parviflora. Number of unique location grid references $\mathrm{x}$ mean grid cell altitude ( $25 \mathrm{~m}$ class intervals). 
The modal mean grid cell altitude is $50-75 \mathrm{~m} \mathrm{AOD}$, and $97 \%$ of locations are $\leq 300$ $\mathrm{m}$. A similar analysis was undertaken for all records of $D$. cespitosa on the BSBI database, excluding those of subsp. parviflora; 110,081 unique grid references. Compared to records only identified to species level, or ascribed explicitly to other infraspecific taxa, subsp. parviflora is proportionately more frequent in the altitude ranges $25-200 \mathrm{~m}$ and $250-275 \mathrm{~m}$. Nearly all localised records of subsp. parviflora $>300 \mathrm{~m}$ AOD are in Wales, the highest reported being at c.365 m AOD at Craig y Moch, Denbighshire (v.c.50).

In the broad sense, $D$. cespitosa reaches a maximum altitude of $1335 \mathrm{~m} \mathrm{AOD}$ on Ben Nevis, West Inverness-shire (v.c.97). While many of the highest altitude records are of $D$. cespitosa subsp. alpina (Alpine Hair-grass), D. cespitosa subsp. cespitosa is found to at least $1000 \mathrm{~m} \mathrm{AOD}$ in the Cairngorm Mountains, and probably higher.

\section{Identification}

A number of features have been reported to distinguish $D$. cespitosa subsp. parviflora from subsp. cespitosa (Table 3). These are discussed in turn, below.

Chiapella and Probatova (2003) put forward two discriminatory characters additional to those listed in Table 3. Awn length: exceeding (or not) the top of their lemmas in subsp. parviflora, cf not exceeding the top of their lemmas in subsp. cespitosa. Spikelets per panicle: 100-150 in subsp. parviflora of $<100$ in subsp. cespitosa. I have not investigated either of these, but it should be noted that $D$. cespitosa is extremely variable (Cope \& Gray 2009).

A combination of woodland or shaded habitat, bright green leaf colour, narrow leaves and delicate panicle, with small spikelets, is suggestive of subsp. parviflora. In combination, leaf blade scabridity on the adaxial surface, appearance of papillae on flat surfaces of adaxial ridges of the leaf, and (accurately measured) spikelet length, provide the most reliable means of distinguishing the two subspecies.

Habitat

Subspecies parviflora is very strongly associated with shaded habitats, principally woodland. I have not found it in fully open habitats. However, in itself, that association is insufficient to identify this taxon.

\section{Leaf colour}

Bright grass-green (Figs 2 and 3), cf the bluish, mid or dark green of subsp. cespitosa. This qualitative difference is consistent in the plants I have examined.

\section{Leaf width}

Viewing a whole tussock, the leaves of subsp. parviflora do tend to appear narrower than those of subsp. cespitosa. However, I failed to find a practical and unbiased method of measuring leaf widths; there is so much variation within a tussock. It is best considered a jizz feature, markedly narrow leaves being possibly suggestive of subsp. parviflora.

\section{Leaf blade scabridity on the adaxial surface}

The ridges on the adaxial (upper) surface of leaves of subsp. cespitosa are armed with forward pointing spines. Hold a leaf firmly between finger and thumb of one 
hand; with your other hand squeeze the leaf blade between finger and the other thumb, and try to move your hand towards the base of the leaf. It will be difficult or impossible to slide your finger and thumb along the leaf in subsp. cespitosa; the leaf is likely to snap in fresh material. If you do the same with a leaf of subsp. parviflora your finger and thumb will slide, relatively easily along the leaf, though with some resistance. Test this with several leaves.

\begin{tabular}{|c|c|c|}
\hline & $\begin{array}{l}\text { D. cespitosa subsp. } \\
\text { parviflora }\end{array}$ & $\begin{array}{l}\text { D. cespitosa subsp. } \\
\text { cespitosa }\end{array}$ \\
\hline Habitat ${ }^{2,3}$ & $\begin{array}{l}\text { Woodland; shade } \\
\text { tolerant plant }\end{array}$ & More open habitats \\
\hline Leaf colour ${ }^{1,3}$ & Bright green & $\begin{array}{l}\text { Bluish-green; medium to } \\
\text { dark green }\end{array}$ \\
\hline Leaf width ${ }^{4}$ & $\begin{array}{l}\text { Narrower than subsp. } \\
\text { cespitosa }\end{array}$ & $\begin{array}{l}\text { Wider than subsp. } \\
\text { parviflora }\end{array}$ \\
\hline $\begin{array}{l}\text { Leaf blade scabridity on the } \\
\text { adaxial surface }{ }^{1,3}\end{array}$ & $\begin{array}{l}\text { Less scabrid than } \\
\text { subsp. cespitosa }\end{array}$ & Coarsely scabrid \\
\hline $\begin{array}{l}\text { Papillae ('spines' sensu } \\
\text { McAllister) on flat surface of } \\
\text { adaxial ridges of leaf } 1,3\end{array}$ & $\begin{array}{l}\text { Appearing as light or } \\
\text { yellowish green } \\
\text { translucent spots (in } \\
\text { living material) }\end{array}$ & $\begin{array}{l}\text { Appearing as more opaque } \\
\text { whitish green spots }\end{array}$ \\
\hline $\begin{array}{l}\text { Spikelet length (mean of } 10 \\
\text { published ranges; original } \\
\text { values at } 0.5 \mathrm{~mm} \text { precision) }{ }^{2}\end{array}$ & $2.1-3.3 \mathrm{~mm}$ & $3.4-5.5 \mathrm{~mm}$ \\
\hline $\begin{array}{l}\text { Spikelet length (range of } \\
\text { spikelet length } \\
\text { measurements by author } \\
\text { (this paper); } 0.1 \mathrm{~mm} \\
\text { precision }^{3}\end{array}$ & $2.6-3.8 \mathrm{~mm}$ & $3.8-5.6 \mathrm{~mm}$ \\
\hline Hairs at base of rhachilla ${ }^{1,6}$ & Shorter than rhachilla, & $\begin{array}{l}\text { Usually longer than } \\
\text { rhachilla }\end{array}$ \\
\hline Hairs on rhachilla ${ }^{1}$ & $\begin{array}{l}\text { Less than half rhachilla } \\
\text { length }\end{array}$ & $\begin{array}{l}\text { More than half rhachilla } \\
\text { length }\end{array}$ \\
\hline Spikelet colour ${ }^{5}$ & Pale green & $\begin{array}{l}\text { Green, dark green or } \\
\text { violaceous, or a mix }\end{array}$ \\
\hline
\end{tabular}

Table 3. Deschampsia cespitosa. Distinguishing features of subspecies parviflora and cespitosa. Sources: ${ }^{1}$ McAllister (1998); ${ }^{2}$ Clapham et al (1987), Stace (2019),

Sell and Murrell (1996), Rose (1989), Cope \& Gray (2009), Parnell \& Curtis (2012), Hubbard (1984), McAllister (1998), Chiapella and Probatova (2003); ${ }^{3}$ Amphlett (this paper), ${ }^{4}$ Cope and Gray (2009); ${ }^{5}$ Chiapella and Probatova (2003); ${ }^{6}$ Stace (2019).

Papillae on flat surface of adaxial ridges of leaf

The flat surfaces, either side of the ridges on the adaxial surface of leaves, support low rounded papillae. McAllister (1998) refers to these structures as 'spines', but that is a misleading description. At x10 magnification, they resemble stomata (or a 
structure surrounding the stomata). However, at x30 they are revealed as papillae. The appearance of these papillae differs between the two subspecies, but to see this requires good illumination and a good quality hand lens. It is best to examine leaves under a low power stereo microscope, ensuring that the angle of incident illumination is kept constant. The appearance of the papillae is best assessed under medium intensity illumination. The papillae of subsp. parviflora are light or yellowish green, appearing as glistening, translucent dots, c.0.03 $\mathrm{mm}$ in diameter, while those of subsp. cespitosa are more easily seen, being larger (c. $0.1-0.2 \mathrm{~mm}$ ), and a more opaque whitish green.

\section{Spikelet length}

All published accounts refer to a difference in spikelet length. Nine Floras and other published accounts give mean minimum and maximum spikelet lengths (extreme values in brackets) of subsp. parviflora (2.0) 2.1-3.3 (3.5) $\mathrm{mm}$ and subsp. cespitosa (3.0) 3.5-5.7 (6.0) $\mathrm{mm}$. The original values are only given to $0.5 \mathrm{~mm}$ precision.

To investigate this character further, I collected single, whole panicles, from 79 tussocks of $D$. cespitosa. Based on leaf colour, leaf blade scabridity on the adaxial surface, and appearance of papillae on the flat surface of adaxial ridges of the leaves, they were allocated to one or other of the subspecies. 42 tussocks were of subsp. parviflora (21 from Scotland (v.c.96) and 21 from England (v.c.s 39 and 57), and 37 tussocks were of subsp. cespitosa from Scotland (v.c.s 95 and 96). Spikelet lengths within a panicle are variable, and an attempt was made to collect an unbiased sample of lengths per panicle, by measuring spikelets from all parts of each panicle. Ten spikelets were measured per panicle, and the mean length calculated. Lengths were measured to $0.1 \mathrm{~mm}$ precision, using a stereo microscope with a calibrated eyepiece graticule. Spikelet length was defined as the straight-line distance from the lowest point of green tissue at the base of the lowest glume to the tip of the hyaline apex of the apical lemma. It is very difficult to accurately measure spikelet lengths in the field. The position of the hyaline apices of the lemmas are easily misjudged, and accurate measurements obtained under a microscope are usually longer than those estimated in the field.

Mean spikelet lengths are shown in Figure 6. Although Cope and Gray (2009) stated that variation in this character is continuous, on the basis of my results it is markedly bimodal. Ranges of mean spikelet lengths in the plants sampled were subsp. parviflora 2.6 - $3.8 \mathrm{~mm}$ and subsp. cespitosa 3.8 - $5.6 \mathrm{~mm}$. The sampled Scottish plants of subsp. parviflora had slightly longer spikelets than the sampled English plants, median 3.4 of $3.1 \mathrm{~mm}$ ( $p<0.05$, Mann Whitney U-test). Insufficient separate populations have been sampled to judge if this difference is of biological interest. That plants differentiated on other morphological grounds differed in spikelet length, adds weight to the distinctiveness of the two subspecies.

Apparently intermediate forms do occur. Two examples measured had mean spikelet lengths of 3.4 and $3.7 \mathrm{~mm}$. Once I had found subsp. parviflora in v.c.96, and gained some appreciation of its preferred habitat, my searching and sampling may have been biased to finding 'good' examples of this subspecies, and I may have avoided habitats where plants were less distinctive. I have looked for subsp. parviflora under A. glutinosa along the banks of the River Spey in Moray v.c.95 and though I have found plants with something of the appearance of this subspecies, 
none have (to date) been convincing. These plants are not included in the above measurements.

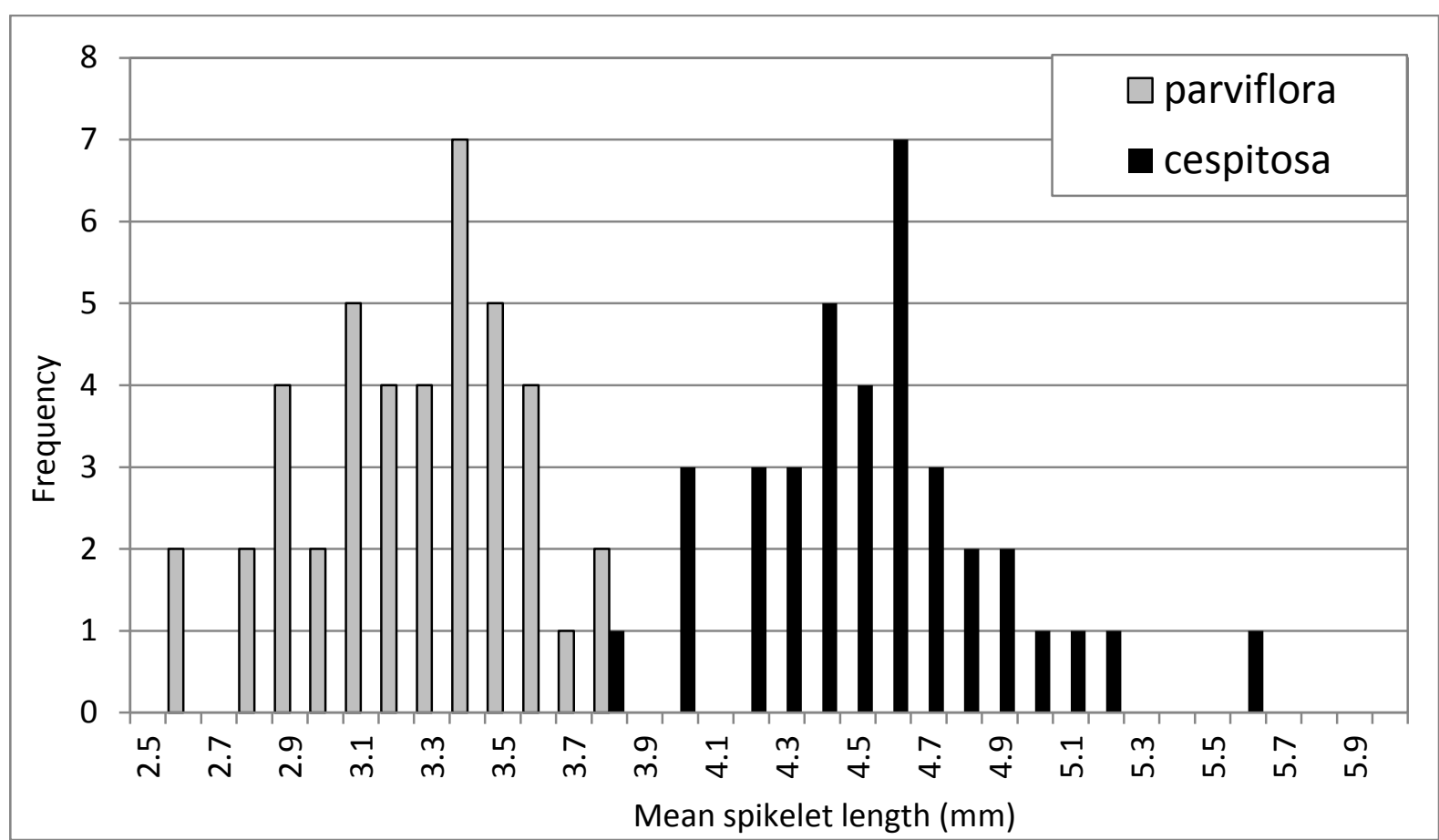

Figure 6. Mean spikelet length, Deschampsia cespitosa subsp. parviflora cf subsp. cespitosa.

\section{Rhachilla hairs}

The relative length of hairs at the base of, and on the rhachilla, I found an impractical character. It is difficult to dissect individual spikelets, and there remains the problem of classifying hairs that are \pm the same length as the supposedly discriminating character.

\section{Spikelet colour}

Spikelets of subsp. parviflora are pale green, and those of subsp. cespitosa are often violaceous, but I have not investigated if the colour difference is reliably consistent. It would, anyway, only be applicable to fresh material.

\section{Conclusion}

Deschampsia cespitosa subsp. parviflora is a distinct taxon, which can be distinguished in the great majority of cases from subsp. cespitosa by a combination of quantitative and qualitative characters. The taxon was not recognised from a European perspective by Clarke (1980), but has been included in Floras of the British Isles since Clapham et al (1952), and was accepted by Chiapella (2000) in his review of $D$. cespitosa in central and northern Europe.

Of 441 hectads in which subsp. parviflora has been recorded in Britain and Ireland, it was first recorded in 381 hectads (86\%) post-1986. Records from several vice-counties where subsp. parviflora is now considered to be fairly frequent, show a marked increase more recently: Derbyshire (v.c.57) from 1997; West Lancashire (v.c.60) from 1998; Cheshire (v.c.58) from 2000; and Worcestershire (v.c.37) from 
2003. There is no reason to suspect that this subspecies is increasing; rather that it had previously been overlooked.

In the course of general botanical recording in north Scotland over the last two years (mainly in v.c.96), of 135 locations where I noted D. cespitosa, $<5 \%$ supported subsp. parviflora. Hence in northern Scotland, subsp. cespitosa is by far the commoner taxon.

\section{References}

Chiapella, J. 2000. The Deschampsia cespitosa complex in central and northern Europe: a morphological analysis. Botanical Journal of the Linnean Society, 134: 495-512.

Chiapella, J. \& Probatova, N.S. 2003. The Deschampsia cespitosa complex (Poaceae: Aveneae) with special reference to Russia. Botanical Journal of the Linnean Society, 142: 213-228.

Clapham, A.R., Tutin, T.G. \& Warburg, E.F. 1952. Flora of the British Isles. Cambridge: Cambridge University Press.

Clapham, A.R., Tutin, T.G. \& Moore, D.N. 1987. Flora of the British Is/es. Cambridge: Cambridge University Press.

Clarke, G.C.S. 1980. Deschampsia account, In Tutin, T.G., Heywood, V.H., Burges, N.A., Moore, D.M., Valentine, D.H., Walters, S.M. \& Webb, D.A., Flora Europaea, Volume 5. Cambridge: Cambridge University Press.

Cope, T. \& Gray, A. 2009. Grasses of the British Isles. BSBI: London.

Dines, T. 2000. A little more Atlas recording in Ireland. BSBI News 84: 78-79.

Farragher, M.A. 1969. Deschampsia caespitosa (L.) Beauv. var parviflora (Thuill.) Coss. and Germ. The Irish Naturalists' Journal: 16, No. 6, p. 177.

Hubbard, C.E. 1984. Grasses. A guide to their Structure, Identification, Uses and Distribution in the British Isles. London: Penguin.

McAllister, H. 1988. Deschampsia cespitosa account, In Rich, T.C.G. \& Rich, M.D.B., Plant Crib. London: BSBI.

McAllister, H. 1998. Deschampsia cespitosa account, In Rich, T.C.G. \& Jermy, A.C., Plant Crib 1998. London: BSBI.

Parnell, J. \& Curtis, T. 2012. Webb's An Irish Flora. Cork: Cork University Press.

Preston, C.D., Pearman, D.A. \& Dines, T.D. 2002. New Atlas of the British and Irish Flora. Oxford: Oxford University Press.

Rose, F. 1989. Colour Identification Guide to the Grasses, Sedges, Rushes and Ferns of the British Isles and north-western Europe. London: Viking.

Stace, C.A. 2019. New Flora of the British Isles. $4^{\text {th }}$ ed. Middlewood Green: C \& M Floristics.

Sell, P. and Murrell, G. 1996. Flora of Great Britain and Ireland. Volume 5. Cambridge: Cambridge University Press.

Copyright retained by author(s). Published by BSBI under the terms of the Creative Commons Attribution 4.0 International Public License.

ISSN: $2632-4970$

https://doi.org/10.33928/bib.2019.01.117 